UDC: $633.11: 631.524 .526 .32: 632.938 .2$

\title{
EXCIZED LEAF WATER STATUS AS A MEASURE OF DROUGHT RESISTANCE OF UKRAINIAN SPRING WHEAT
}

\author{
O. O. Makar ${ }^{1 *}$, O. I. Patsula1, Y. Z. Kavulych ${ }^{1}$, T. I. Batrashkina1, \\ L. V. Bunio', V. I. Kozlovskyy', O. Vatamaniuk ${ }^{3}$, O. I. Terek', N. D. Romanyuk ${ }^{1}$ \\ ${ }^{1}$ Ivan Franko National University of Lviv, 4, Hrushevskyi St., Lviv 79005, Ukraine \\ 2 Institute of Ecology of the Carpathians, NAS of Ukraine, 4, Kozelnytska St., Lviv 79000, Ukraine \\ ${ }^{3}$ Soil and Crop Sciences Section, School of Integrative Plant Sciences, \\ Cornell University, Ithaca, NY, United States \\ *Corresponding author: orysia.makar@Inu.edu.ua
}

Makar O.O., Patsula O.I., Kavulych Y.Z., Batrashkina T.I., Bunio L.V., Kozlovskyy V.I., Vatamaniuk O., Terek O.I., Romanyuk N.D. Excized leaf water status as a measure of drought resistance of Ukrainian spring wheat. Studia Biologica, 2019: 13(2); 41-54 • DOI: https://doi.org/10.30970/ sbi.1302.604

Drought tolerance of 24 Ukrainian spring wheat (Triticum aestivum L., T. durum Desf., T. turgidum subsp. dicoccum) genotypes was estimated by determining water deficit (WD), relative water content (RWC), excised leaves water loss weight (EL WLW), excised leaves water loss per area (EL WLA) in flag leaves of plants grown in a field conditions during Y2018 vegetative season, that was characterized by low precipitation and high temperatures. Field experimental plots were located near Dmytriv village, Lviv region $\left(50^{\circ} 13^{\prime} 26.6^{\prime \prime} \mathrm{N} 24^{\circ} 36^{\prime} 50.5^{\prime \prime} \mathrm{E}\right)$ on the Chernozem on eluvium of carbonate rock soil. Wheat was sown in a randomized complete block design in four replications of $30 \mathrm{~m}^{2}$ plot area. The purpose of this study was to verify more reliably a physiological traits used for screening of the performance under the restricted water supply and to correlate the varietal tolerance with the final grain yield. Water status parameters were determined on the Zadoks 4.3 growth stage. Water deficit caused a reduction in the leaf RWC for all studied varieties. Differences in the drought response between $T$. aestivum and $T$. durum varieties were confirmed. The WD of flag leaves ranged from 18.0 to $37.8 \%$ for bread and from 19.4 to $33.3 \%$ for durum wheat varieties. The lowest WD (less or equal $20 \%$ ) has been recorded for bread varieties Kolektyvna 3, Elehiia myronivs'ka and durum varieties - Diana, Chado. High WD noted for the Simkoda myronivs'ka and MIP Raiduzhna. The low EL WLW and therefore higher drought tolerance was noticed for durum wheat varieties, namely for Spadschyna, Diana. Bread wheat varieties Simkoda myronivs'ka, Panianka, and durum wheat Zhizel', Tera, MIP Raiduzhna and emmer

(C) 2019 О. O. Makar et al.; Published by the Ivan Franko National University of Lviv on behalf of Біологічні Студії / Studia Biologica. This is an Open Access article distributed under the terms of the Creative Commons Attribution License (http://www.budapestopenaccessinitiative.org/ and Creative Commons Attribution 4.0 License), which permits unrestricted reuse, distribution, and reproduction in any medium, provided the original work is properly cited.

ISSN 1996-4536 (print) • ISSN 2311-0783 (on-line) • Біологічні Студії / Studia Biologica • 2019 • Том 13/№2 • С. 41-54 
Holikovs'ka varieties lost less water per leaf area (EL WLA). Past 3 biplot correlation analysis confirmed MIP Raiduzhna drought tolerance, and allowed to choose Zhizel' (durum), Holikovs'ka (emmer) and Simkoda myronivs'ka (bread) as varieties with a high yield performance and drought tolerance. Bread varieties Bozhena and Dubravka, durum Spadschyna, Diana varieties were susceptible to drought in spite of relatively high leaf RWC. Thus, excised leaves water loss - EL WLW and EL WLA indices characterizing water-retaining ability of leaf tissues could be recommended as additional indicators of water stress tolerance. RWC as drought tolerance parameter is more applicable for durum varieties, whereas EL WLA 2-6 h for the bread varieties.

Keywords: drought, Ukrainian spring wheat, relative water content, water deficit, excised leaves water loss, EL WLW, EL WLA

\section{INTRODUCTION}

Wheat is a worldwide important crop and one of the main calories sources in human diet (19\%) and for feeding of poultry and livestock (40\%) [34]. It is very important for the Ukrainian agriculture sector [21; 3]. Despite the traditionally large sawing areas of the winter wheat, recently in Europe, and especially in Ukraine, we observe an increase of a spring wheat importance [38; 19]. A tetraploid emmer wheat became more popular which has a high grain quality used in dietary nutrition and possess a morphophysiological traits conferring drought resistance [29; 24; 20].

Facing climate changes [26; 27; 28; 31], springs in Europe became more often accompanied with drought, air storms, uneven precipitation and temperatures; summers by severe drought that caused unfavorable growth conditions for many crops [25; 32; 37]. According to the CORDEX data temperatures in Ukraine to 2070 will increase for 1.65 $2.98{ }^{\circ} \mathrm{C}$, with changes in precipitation character. Thus, the decrease of overall wheat production by $6-11 \%$ is predicted. In these conditions, an important challenge to cope with possible shortage of food supply for growing human population is to improve wheat drought tolerance $[4 ; 26 ; 37]$. In that case, an important issue is improvement of the drought tolerance assessment by the express field and physiological laboratory methods.

The main goal of our study was to verify more reliably a physiological traits used for screening the performance on a twenty four wheat genotypes from the State Register of Plant Varieties Suitable for Dissemination in Ukraine [36] under the restricted water supply in field conditions, and to correlate the tolerance of these varieties with the final grain yield. Relative water content (RWC), water deficit (WD), excised leaves water loss weight (EL WLW), excised leaves water loss per area (EL WLA) of flag leaves and final yield of plants subjected the drought stress in field conditions were determined.

\section{MATERIALS AND METHODS}

Plant material. 24 spring wheat genotypes (V.M. Remeslo Myronivka Institute of Wheat of NAAS, The Plant Production Institute V.Ya.Yuryev of NAAS, Nosivka Station of Selection and Research breeding) were grown in field experiment during the Y2018 crop season.

The studied genotypes were grouped into 3 categories: 15 varieties of hexaploid bread wheat (Triticum aestivum L.); 8 varieties of durum wheat (Triticum turgidum subsp. durum Desf.);1 variety of tetraploid emmer wheat (Triticum turgidum subsp. dicoccum) (Table 1).

ISSN 1996-4536 (print) • ISSN 2311-0783 (on-line) • Біологічні Студії / Studia Biologica • 2019 • Том 13/№2 • С. 41-54 
Table 1. Taxonomic classification of spring wheat varieties used in the study Таблиця 1. Таксономічна класифікація сортів ярої пшениці, використаних удослідженні

\begin{tabular}{c|c}
\hline Genotype & Taxonomic classification \\
\hline $\begin{array}{c}\text { Kolektyvna 3, Oksamyt myronivs'kyi, Panianka, } \\
\text { Bozhena, Elehiia myronivs'ka, Simkoda myronivs'ka, } \\
\text { Provintsialka, Heroinia, Kharkivs'ka 30, Uliublena }\end{array}$ & Triticum aestivum L. \\
\hline Izol'da, MIP Raiduzhna, Diana, Tera, Spadschyna, Chado, \\
Dynastiia, Zhizel' & $\begin{array}{c}\text { Triticum turgidum } \\
\text { subsp. durum Desf. }\end{array}$ \\
\hline Holikovs'ka & $\begin{array}{c}\text { Triticum turgidum } \\
\text { subsp. dicoccum }\end{array}$ \\
\hline
\end{tabular}

As standards for drought tolerance Elehiia myronivs'ka (bread) and MIP Raiduzhna (durum) varieties were used [13; 19].

Experimental details. Field experimental plots were located near Dmytriv village, Radekhiv district, Lviv region $\left(50^{\circ} 13^{\prime} 26.6^{\prime \prime} \mathrm{N} 24^{\circ} 36^{\prime} 50.5^{\prime \prime} \mathrm{E}\right)$. The soil type was Chernozem on eluvium of carbonate rock [45], with $\mathrm{pH}$ (7.13-7.52), content of organic matter $74.56 \mathrm{~g} / \mathrm{kg}$.

Wheat seeds were sown on April, 2018 in a randomized complete block design in four replications, plot area $30 \mathrm{~m}^{2}$ (5×6 meters), row spacing $0.20 \mathrm{~m}$; seeded at an average rate of $125 \mathrm{~kg} \mathrm{ha}^{-1}$ with hand planter. The whole dose of nutrients i.e. nitrogen $120 \mathrm{~kg} \mathrm{ha}^{-1}$ and $\mathrm{P}_{2} \mathrm{O}_{5} 10 \mathrm{~kg} \mathrm{ha}^{-1}, \mathrm{~K}_{2} \mathrm{O} 29 \mathrm{~kg} \mathrm{ha}^{-1}$ was used the time of seedbed preparation.

As indices of plant water stress status, we estimated water deficit (WD), relative water content (RWC), excised leaf water loss per weight (EL WLW) and per area (EL WLA) of excised flag leaves, collected from plants at the Z4.3 stage according to Zadoks decimal growth stages classification [44].

During the first decade of June, 10 flag leaves from each experimental plot were randomly selected and excised in accordance with each variety growth stage. The leaves were placed in polyethylene zip-bags and immediately transported to the laboratory.

Leaves were weighted several times on an electronic balance (Radwag AS 310.R2, Ukraine); immediately after sampling we determined leaf fresh weight (FW), after $12 \mathrm{~h}$ in water the leaves were weighed to obtain turgid weight (TW), then the leaf was placed on a filter paper in laboratory conditions and weighed by 2, 4, 6 and $24 \mathrm{~h}$. Dry weight (DW) was measured after oven-drying at $105^{\circ} \mathrm{C}$.

The water deficit (WD) was calculated as [16]:

$$
\text { WD }(\%)=\frac{T W-F W}{T W} \cdot 100 \text {. }
$$

Relative water content (RWC) was defined according to the formula of Weatherly [39; 40]:

$$
\operatorname{RWC}(\%)=\frac{(F W-D W)}{(T W-D W)} \cdot 100
$$

ISSN 1996-4536 (print) • ISSN 2311-0783 (on-line) • Біологічні Студії / Studia Biologica • 2019 • Том 13/№2 • С. 41-54 
Excised leaves water loss weight (EL WLW) index was determined with Arlando method [11] based on calculation of water loss by excised leaves during fixed time periods, e.g. $-2,4,6,24 \mathrm{~h}$ :

$$
\text { EL WLW } \text { 0-"x"h }(\%)=100-\frac{\text { weight after "x"h-100 }}{\text { TW }}
$$

where: weight after "x"h - leaf weight after 2, 4, 6 and $24 \mathrm{~h}$.

Excised leaves water loss area (EL WLA) was calculated as water loss per area after 2, 4, 6 and 24 h. EL WLA as rate of water loss $/ \mathrm{cm}^{2}$, as proposed by Clarke [9] was calculated from the following formula:

$$
E L W L A_{0-" x " h}\left(\mathrm{mg} / \mathrm{cm}^{2}\right)=\frac{T W-\text { weight after "x"h }}{\mathrm{LA}},
$$

where: weight after "x"h - leaf weight after 2, 4, 6 and 24 h, LA - leaf area.

The leaf area was calculated using leaf images with the Adobe Photoshop 7.0 software.

Grain yield of wheat is determined as (number of heads from $\left.1 \mathrm{~m}^{2}\right) \times($ kernels/grain per head $) \times($ kernel/grain weight $)$.

Statistical Analysis. Microsoft Excel Program was used for the graphical presentation of data, descriptive statistics and correlation analysis, principal component analysis was performed using freeware data analyzer software Past 3 [46].

\section{RESULTS AND DISCUSSION}

Rainfalls and mean temperatures during Y2018 crop season and previous seasons Y2016, Y2017 are presented in the Table 2. The Y2018 season was characterized by a relatively dry period from the April to the end-June, followed by a relatively humid period lasting from 25th of June to mid-July. April-May rainfall was $75.3 \mathrm{~mm}$, compared with the long-term average of $130 \mathrm{~mm}$. The average air temperature in April 11, 2018, when seeds were sown was fixed at $13.5^{\circ} \mathrm{C}$, and the lack of precipitation during this month $(24 \mathrm{~mm})$ caused a serious water deficit condition. Similar conditions were observed in May during vegetative growth - water deficit and high temperatures. A "2018 European drought and heat wave" as a period of unusually hot weather during the spring and summer was reported [47].

Table 2. Weather conditions in Radekhiv district (Lviv region) during April-June, 20162018

Таблиця 2.Кліматичні умови у Радехівському районі (Львівська область) у квітнічервні 2016-2018 рр.

\begin{tabular}{c|c|c|c|c}
\hline \multirow{2}{*}{$\begin{array}{c}\text { Climatic } \\
\text { parameters }\end{array}$} & Years & \multicolumn{3}{|c}{ Month } \\
\cline { 2 - 5 } & 2018 & April & May & June \\
\cline { 2 - 5 } Rainfall, mm & 2017 & 48.7 & 51.3 & 153.4 \\
\cline { 2 - 5 } & 2016 & 65.1 & 80.5 & 31.4 \\
\hline \multirow{3}{*}{ Temperature, ${ }^{\circ} \mathrm{C}$} & 2018 & 13.5 & 68.8 & 115.6 \\
\cline { 2 - 5 } & 2017 & 8.1 & 17.0 & 18.3 \\
\cline { 2 - 5 } & 2016 & 10.1 & 13.7 & 18.1 \\
\hline
\end{tabular}

ISSN 1996-4536 (print) • ISSN 2311-0783 (on-line) • Біологічні Студії / Studia Biologica • 2019 • Том 13/№2 • С. 41-54 
Water deficit characteristics and leaf relative water content of flag leaves. There were genotypic differences in initial leaf water content at all samplings and in change in leaf water content after $24 \mathrm{~h}$. Under natural drought conditions, the WD of flag leaves ranged from 18.0 to $37.8 \%$ for bread and from 19.4 to $33.3 \%$ for durum varieties (Fig. 1). The lowest WD (less or equal $20 \%$ ) have been recorded for bread wheat varieties Kolektyvna 3, Elehiia myronivs'ka and durum varieties - Diana, Chado. High WD was noted for the Simkoda myronivs'ka and MIP Raiduzhna - 37.8 \% and $33.3 \%$, respectively.

RWC of Elehiia myronivs'ka leaves as the standard drought tolerant variety [13] assessed on the level of $72 \%$ (Fig. 1), higher than $75 \%$ RWC revealed for two bread wheat varieties - Etiud, Kolektyvna 3; and one durum - Chado variety. The lowest RWC, less than $53 \%$, recorded for the sensitive Simkoda myronivs'ka (bread) and MIP Raiduzhna (durum) varieties. The tetraploid emmer Holikovs'ka had also a comparatively high RWC (70\%).
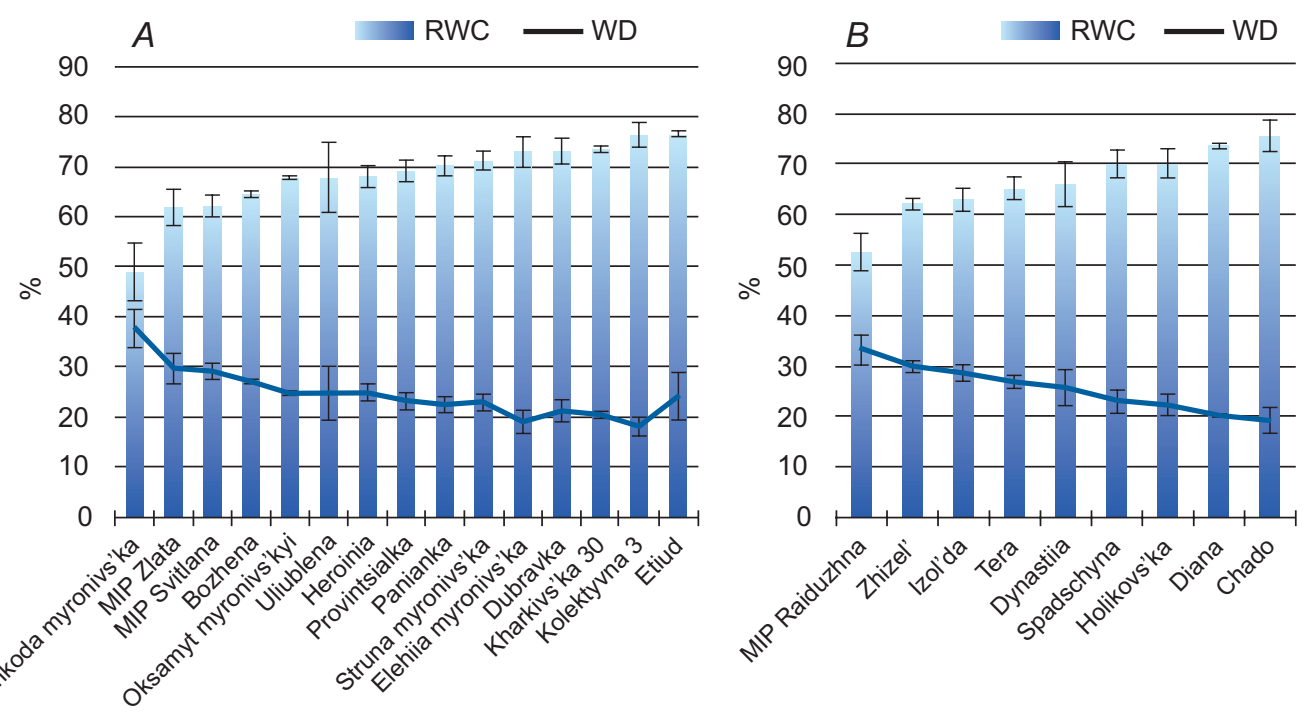

Fig. 1. The flag leaf water deficit (WD) and relative water content (RWC) of bread $(A)$ and durum $(B)$ spring wheat varieties on Z4.3 stage in the field experiment, Dmytriv location $\left(50^{\circ} 13^{\prime} 26.6^{\prime \prime} \mathrm{N} 24^{\circ} 36^{\prime} 50.5^{\prime \prime} \mathrm{E}\right)$ Y2018 crop season

Рис. 1. Водний дефріцит (WD) та відносний вміст води (RWC) у листках сортів пшениці м'якої (A) і твердої (B) ярої на етапі Z4.3 у польових умовах, вегетаційний сезон 2018 р., с. Дмитрів (50²13'26,6" $\left.24^{\circ} 36^{\prime} 50,5^{\prime \prime} \mathrm{E}\right)$

In general, there were non-significant differences between studied hexa- and tetraploid wheat genotypes. According to literature data, the typical RWC at about wilting point for the majority crop species is close $60 \%$ to $70 \%$ [23]. Assuming that RWC $40 \%$ is noted for a severely desiccated and dying leaves all varieties were subjected the drought stress under the Y2018 studied climatic conditions.

Excised leaves water loss. EL WL as indices of a excised flag leaves water retention capability was calculated separately per dry weight (Fig. 2, A-B) and per leaf area (Fig. 2, C-D). The highest rates of water loss were noted on the 2 nd $\mathrm{h}$ of desiccation. 


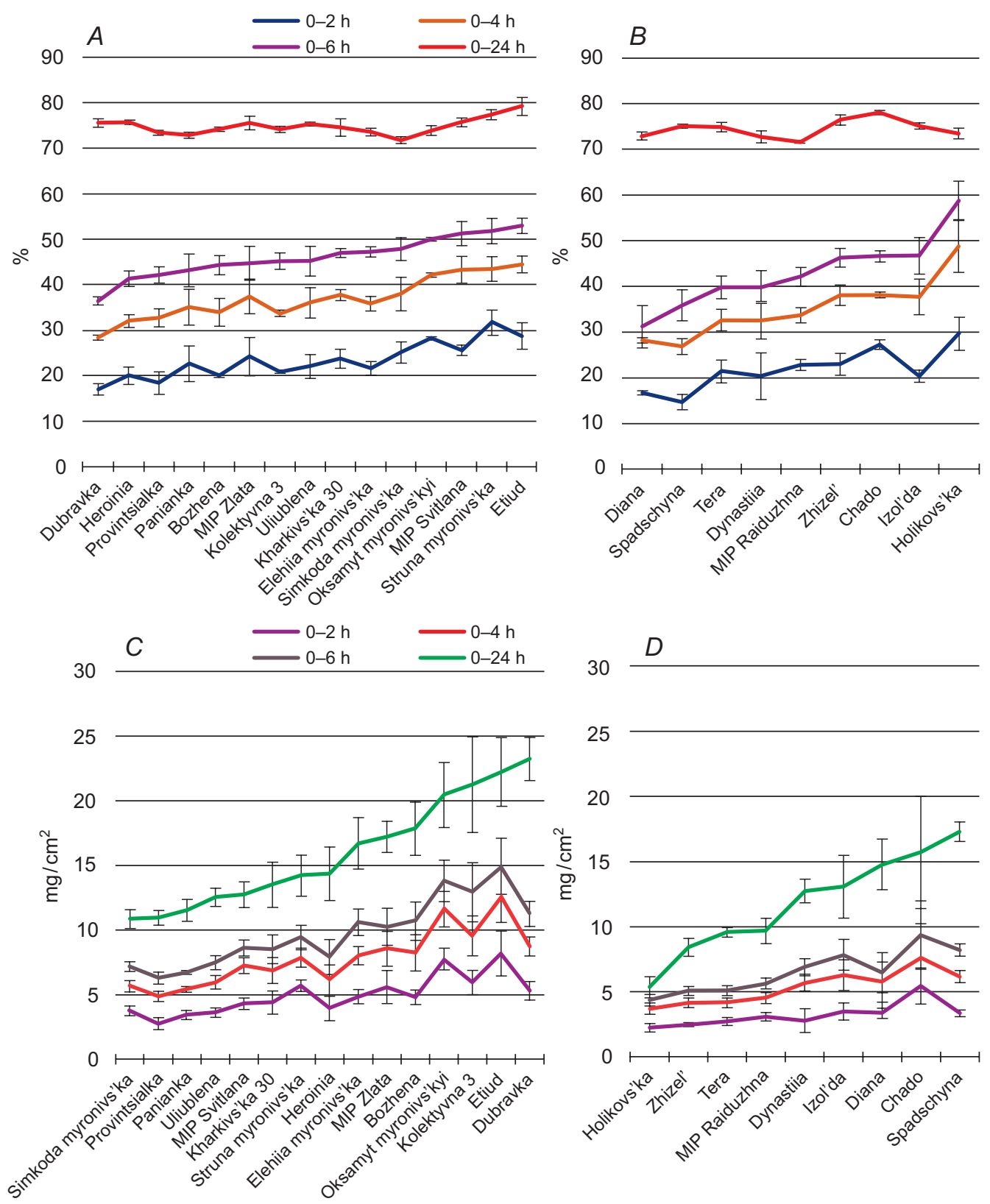

Fig. 2. Excised leaves water loss weight (EL WLW) of bread $(A)$ and durum $(B)$ wheat, excised leaves water loss area (EL WLA) of bread $(C)$ and durum $(D)$ wheat on $0-2,0-4,0-6$ and $0-24 \mathrm{~h}$ for flag leaf of spring wheat varieties on Z4.3 stage in the field experiment, Dmytriv location $\left(50^{\circ} 13^{\prime} 26.6^{\prime \prime} \mathrm{N}\right.$ $24^{\circ} 36^{\prime} 50.5^{\prime \prime}$ ) Y 2018 crop season

Рис. 2. Водоутримна здатність у перерахунку на масу (ELWLW) і площу (EL WLA) прапорцевих листків (Z4.3) сортів пшениці м'якої $(A, C)$ та твердої $(B, D)$ ярої на $0-2,0-4,0-6$ та 0-24 год в умовах

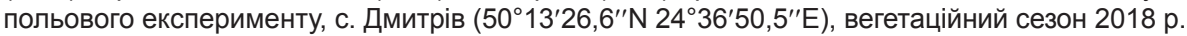


The lowest EL WLW have been shown for such durum wheat as Spadschyna $14.7 \%$, and Diana - $16.7 \%$ with a high WD. For bread wheat, low EL WLW water losses have been noted for Dubravka - $17.0 \%$ and Provintsialka - $18.4 \%$. While the high EL WLW were obtained for Struna myronivs'ka bread wheat $31.7 \%$, Chado durum wheat $27.3 \%$ and Holikovs'ka emmer wheat $29.6 \%$.

The studied varieties tended to lose most moisture during the second and third 2-h periods. The low EL WLW has been obtained for the bread wheat Dubravka, Heroinia, Provintsialka - 28-42 \% if compare with the maximum EL WLW noticed for MIP Svitlana, Struna myronivs'ka, Etiud 43-52 \%. For durum varieties the lowest EL WLW was noted for Spadschyna, Diana - 27-36 \%, whereas the biggest water losses have been established for the Zhizel', Chado, Izol'da varieties $-37-46 \%$ on 4-6 h of experiment. For the emmer variety Holikovs'ka on $4 \mathrm{~h}$ and $6 \mathrm{~h}$ time points, the highest EL WLW, a $48.7 \%$ and $58.7 \%$, respectively were observed. On 24th h of desiccation EL WLW achieved its maximum $72-79 \%$, and there were not significant differences between the studied genotypes.

The EL WLA indices were different from EL WLW. Bread wheat Simkoda myronivs'ka, Provintsialka, Panianka, and durum wheat Zhizel', Tera, emmer Holikovs'ka lost less water per leaf area unit, and maximum water losses were recorded for bread Etiud, Dubravka and durum Chado, Spadschyna varieties. The greatest water loss during 2-6 h was noticed for bread wheat Oksamyt myronivs'kyi, Kolektyvna 3 and Etiud, for durum - Chado and Spadschyna.

The results of principal component analysis (PCA) are shown on Fig. 3. The Component 1 contributed to $43,7 \%$, of the total variation, the Component 2 - to $28.4 \%$.

The acute angles between the PC vectors of the EL WLW 2-6 $h$, and EL WLA 2-6 h, RWC indices showed that these parameters are associated. Grain yield slightly positively correlated with Component $2(0.17)$, and negatively $(-0.13)$, with Component 1 . This means that grain yield slightly depended on other factors. The PC graphs revealed that grain yield negatively associated with EL WLA 2-6 h. Considering the length of vectors, the most important indices were EL WLW 2-6 h, and EL WLA 2-6 h, whereas the same indices on $24 \mathrm{~h}$ of desiccation and initial RWC were less informative in the analysis. Emmer Holikovs'ka has a distinct position on the graph with high water retaining ability and yield characteristics. Biplot shows that varieties Zhizel', MIP Raiduzhna, Simkoda myronivs'ka are in a vicinity of indicators of drought tolerance and yield performance. Bread varieties Kolektyvna 3, Etiud are in the vicinity of indicators of sensitivity; varieties Bozhena and Dubravka - close to the vectors of sensitivity and tolerance, therefore according to the proposed model of biplot analysis [1], these genotypes are susceptible to drought and have normal adaptation to the environment.

Water deficit limits crop productivity, so breading for a minimal yield loss in such environments becomes an important issue under climate changes, growing our population and land-use pressure $[13 ; 19 ; 42]$. Lack of the moisture during the wheat tillering stage causes an increase of infertile spikes, and as a result, a significant yield loss in wheat are observed [12; 32; 43].

There is a relationship between crops drought resistance and high amount of relative water, water potential [10; 33] and membrane integrity. According to A. Kamoshita et al. and other reports [17; 2], genotypes that keep a higher RWC are more droughtresistant, on the other hand RWC depends on the ontogenesis stage [9]. The greater decrease of RWC under drought relates to a capacity of tolerant varieties to better absorb water from soil and to prevent transpiration losses [5; 14]. N. Sobhaninan et al.

ISSN 1996-4536 (print) • ISSN 2311-0783 (on-line) • Біологічні Студії / Studia Biologica • 2019 • Том 13/№2 • C. 41-54 
reported RWC strongest indirect effect on grain yield under the drought [35]. High RWC and leaf water potential under drought are reported for the durum tetraploid wheat. The results obtained in our experiment on the basis of RWC suggest the following water deficit tolerant varieties: Etiud, Kolektyvna 3 for bread wheat, and Chado, Diana, Holikovs'ka for durum wheat.

$A$

\begin{tabular}{|l|c|c|c|c|c|c|c|c|}
\hline & PC 1 & PC 2 & PC 3 & PC 4 & PC 5 & PC 6 & PC 7 & PC 8 \\
\hline RWC & 0.40 & -0.40 & -0.47 & 0.71 & -0.04 & -0.01 & 0.01 & 0.001 \\
\hline WLW 2 h & 0.69 & 0.66 & -0.04 & -0.04 & -0.28 & 0.03 & 0.08 & -0.007 \\
\hline WLW 4 h & 0.68 & 0.69 & -0.13 & 0.02 & 0.12 & -0.14 & -0.01 & 0.03 \\
\hline WLW 6 h & 0.76 & 0.59 & -0.16 & 0.01 & 0.16 & 0.12 & -0.06 & -0.02 \\
\hline WLA 2 h & 0.83 & -0.42 & 0.28 & -0.04 & -0.21 & -0.01 & -0.10 & 0.02 \\
\hline WLA 4 h & 0.85 & -0.48 & 0.17 & -0.07 & 0.09 & -0.06 & 0.03 & -0.06 \\
\hline WLA 6 h & 0.81 & -0.53 & 0.16 & -0.08 & 0.13 & 0.06 & 0.07 & 0.04 \\
\hline Grain yield & -0.14 & 0.40 & 0.76 & 0.49 & 0.04 & 0.01 & 0.01 & -0.001 \\
\hline
\end{tabular}

$B$

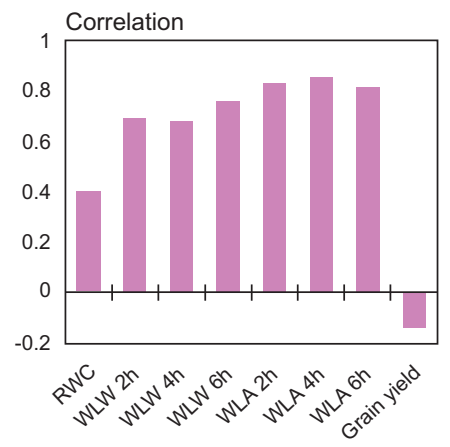

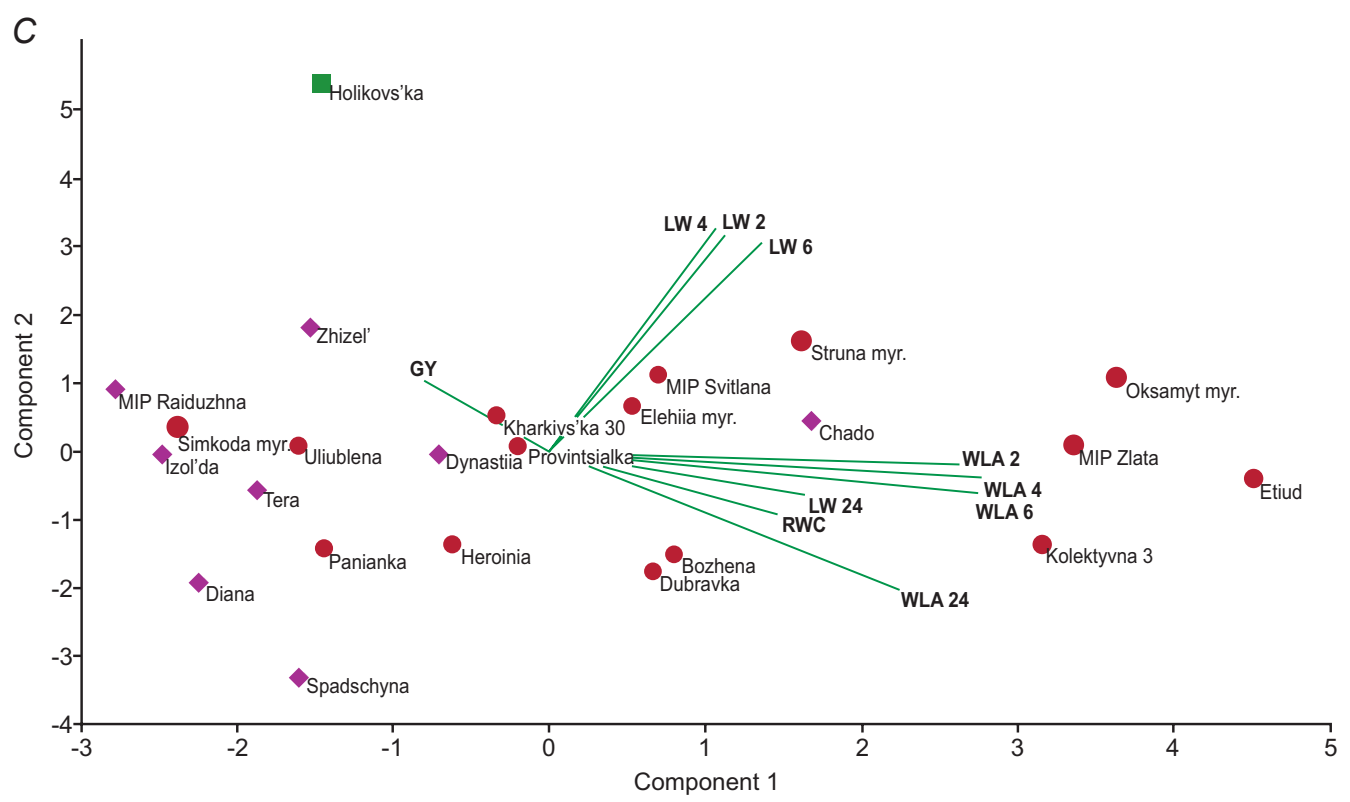

Fig. 3. Traced graphics of Biplot drought tolerance indices and yield performance of spring wheat varieties based on the first two components. $A$ - loading factor of varietal traits, $B$ - correlation, $C$ - scatter plot. $\mathrm{PC}=$ principal components, PC1 to PC8 of studied wheat traits. RWC - relative water content, LW excised leaf water loss per dry weight (EL WLW); WLA - excised leaf water loss per leaf area (EL WLA) on 2, 4, 6, 24 h of desiccation; GY - grain yield, kg per $\mathrm{m}^{2}$. Varieties as described in the Table 1

Рис. 3. Двокомпонентний biplot аналіз показників посухостійкості та врожайності сортів пшениці ярої. $A$ - матриця навантажень, $B$ - кореляція, $C$ - діаграма розкиду. PC = головні компоненти, PC1PC8 - основні досліджувані параметри пшениці. RWC - відносний вміст води, LW - водоутримна здатність у перерахунку на масу сухої речовини (EL WLW); WLA - втрати води на одиницю площі листка (EL WLA) на 2, 4, 6, 24 год висушування; GY - урожай зерна, кг на м². Сорти описано в табл. 1 
The high rate of EL WL negatively correlated with wheat grain yield under the drought conditions [15; 7]. There are also reports that bread wheat varieties are more stable to a lack of water in the soil than durum [41]. Due to poor root system and low water-retaining ability of leaves at the initial period of growth of durum wheat, the bread wheat has higher heritable water retention capacity trait [7]. On the other hand, there are a lot of data confirming higher drought tolerance of durum wheat varieties [8]. A better growth under water stress in $T$. durum and $T$. dicoccum, as compared to hexaploid genotypes were, associated with their better water retention capacity that may be linked to ABA content, lower pigment bleaching, higher membrane stability, and nitrate reductase activity [11]. Therefore, RWC or ELWL are used broadly as a selection tool indicating drought tolerance.

Taking into accounts the obtained data, it could be assumed that EL WLW values which reflected drought resistance decrease in the following order: Dubravka-HeroiniaProvintsialka-Panianka-Bozhena for bread wheat and Spadschyna-Diana-DynastiiaTera-MIP Raiduzhna for durum wheat.

EL WL might more closely reflect the balance between water supply to the leaf and a transpiration rate. This improves the ability of the plant to recover from stress and consequently the grain yield and its stability. This parameter can be easily determined and is hence applicable for use in large populations [18].

According to I.V. Boichuk et al. [6], water retaining ability of winter wheat leaves had a significant variability depending on the phase of plant development and genotype, showed different water losses during 4 and $8 \mathrm{~h}$. Weighing of leaves $24 \mathrm{~h}$ after excision may be acceptable early, but not late in the season [9]. The above correlation reported as strong in a bread wheat, and statistically insignificant in durum wheat [22]. In general, the adaptive capacity were also highlighted for the varieties Struna myronivs'ka and Elehiia myronivs'ka.

Water deficit of spring wheat flag leaves was mostly determined by the varietal features. Thus, EL WLA as well RWC, are effective as screening tools for drought tolerance in different wheat varieties. According to our data a correlation between water retaining ability and water deficit indices in spring wheat leaves does not always occur. According to the literary data especially sensitive to water deficit is a reproductive phase.

Thus, the excised leaves water loss - EL WLW and EL WLA characterizing waterretaining capability of leaf tissues as additional indicators of water stress tolerance were difined.

\section{CONCLUSIONS}

All wheat varieties were subjected a severe drought stress under the Y2018 studied climatic conditions. The WD of flag leaves ranged from 18.0 to $37.8 \%$ for bread and from 19.4 to $33.3 \%$ for durum wheat varieties. The lowest WD were recorded for bread varieties Kolektyvna 3, Elehiia myronivs'ka and durum varieties - Diana, Chado.

Biplot correlation analysis of drought tolerance indices and yield performance revealed that varieties Zhizel', MIP Raiduzhna, Simkoda myronivs'ka are in a vicinity of indicators of drought tolerance and yield performance. Bread varieties Bozhena and Dubravka are susceptible to drought and have normal adaptation potential to the environment. Emmer wheat Holikovs'ka has a distinct high leaf water retaining ability and yield characteristics.

ISSN 1996-4536 (print) • ISSN 2311-0783 (on-line) • Біологічні Студії / Studia Biologica • 2019 • Том 13/№2 • C. 41-54 
Thus, excised leaves water loss - EL WLW and EL WLA indices characterizing water-retaining ability of leaf tissues could be recommended as additional indicators of water stress tolerance. RWC as effective express screening tool for drought tolerance is more applicable for durum wheat varieties, whereas excised flag leaf water loss per area (EL WLA) 2-4 h, for bread wheat varieties.

\section{ACKNOWLEDGMENTS}

This research was partially supported by the CRDF grant, Project OISE 16-62755-0. The V.M. Remeslo Myronivka Institute of Wheat of NAAS, The Plant Production Institute V.Ya.Yuryev of NAAS, Nosivka Station of Selection and Research for the seed material provided for research. Barkom company assisted in performing of field experiments.

\section{CONFLICTS OF INTEREST}

The authors declare no conflict of interest.

1. Abdi H., Mazandarai M.T. Study of Drought Tolerance in Bread Wheat Cultivars Using Biplot. International Journal of Life-Sciences Scientific Research, 2016; 2(6): 651-657. [DOI: https://doi.org/10.21276/ijlssr.2016.2.6.2]

2. Arjenaki F.G., Jabbari R., Morshedi A. Evaluation of Drought Stress on Relative Water Content, Chlorophyll Content and Mineral Elements of Wheat (Triticum aestivum L.) Varieties. Journal of Agriculture and Crop Sciences, 2012; 4(11): 726-729.

3. Bazalii V.V., Boichuk I.V., Babenko D.V., Bazalii G.G. The character of formation and manifestation of winter hardiness in hybrids and varieties of winter soft wheat under the conditions of Southern Ukraine. Tavria Scientific Bulletin, 2016; 95: 9-15. (In Ukrainian)

4. Biesaga-Kościelniak J., Ostrowska A., Filek M., Dziurka M., Waligórski P., Mirek M., Kościelniak J. Evaluation of Spring Wheat (20 Varieties) Adaptation to Soil Drought during Seedlings Growth Stage. Agriculture, 2014; 4(2): 96-112.

[DOI: https://doi.org/10.3390/agriculture4020096]

5. Bilal M., Iqbal I., Rana R.M., Shoaib Ur Rehman, Haidery Q-ul-A, Ahmad F., ljaz A., Umar H.M.I. A comprehensive review of effects of water stress and tolerance in wheat (Triticum aestivum L.). Tropical Plant Research, 2015; 2(3): 271-275.

6. Boichuk I.V., Bazalii V.V., Bazalii G.G., Domaratskyi Ye.O. Water retention ability of winter wheat as a criterion for evaluating drought resistance of varieties under different growing conditions. Tavria Scientific Bulletin, 2012; 82: 25-29. (In Ukrainian)

7. Chandra D, Islam M.A. Genetic variation and heritability of excised-leaf water loss and its relationship with yield and yield components of $F_{5}$ bulks in five wheat crosses. Journal of Biological Sciences, 2003; 3(11): 1032-1039.

[DOI: https://doi.org/10.3923/jbs.2003.1032.1039]

8. Chandrasekar V., Sairam R.K., Srivastava G.C. Physiological and Biochemical Responses of Hexaploid and Tetraploid Wheat to Drought Stress. Journal of Agronomy and Crop Science, 2000; 185(4): 219-227. [DOI: https://doi.org/10.1046/j.1439-037x.2000.00430.x]

9. Clarke J.M., McCaig T.N. Excised-leaf water retention capability as an indicator of drought resistance of Triticum genotypes. Canadian Journal of Plant Science, 1982; 62(3): 571-578. [DOI: https://doi.org/10.4141/cjps82-086]

10. Clarke J.M., McCaig T.N., DePauw R.M., Knox R.E., Clarke F.R., Fernandez M.R., Ames N.P. Strongfield durum wheat. Canadian Journal of Plant Science, 2005; 85(3): 651-654. [DOI: https://doi.org/10.4141/p04-119]

ISSN 1996-4536 (print) • ISSN 2311-0783 (on-line) • Біологічні Студії / Studia Biologica • 2019 • Том 13/№2 • C. 41-54 
11. Czyczyło-Mysza I.M., Marcińska I., Skrzypek E., Bocianowski J., Dziurka K., Rančić D., Radošević R., Pekić-Quarrie S., Dodig D., Quarrie S.A. Genetic analysis of water loss of excised leaves associated with drought tolerance in wheat. PeerJ6: e5063, 2018. [DOI: https://doi.org/10.7717/peerj.5063]

12. Demydov O., Kavunets V., Siroshtan A., Gudzenko V., Khomenko S. Spring bread wheat requires attention. Propozytsiia, 2017; 1: 76-80. (In Ukrainian)

13. Demydov O.A., Khomenko S. O., Fedorenko I.V., Blyzniuk R.M., Kuzmenko Ye.A. Assessment of adaptive capacity of spring wheat lines under conditions of Forest-Steppe zone of Ukraine.

Plant Varieties Studies and Protection, 2016; 1(30): 57-61. (In Ukrainian) [DOI: https://doi.org/10.21498/2518-1017.1(30).2016.61778]

14. Eftekhari A., Baghizadeh A., Yaghoobi M.M., Abdolshahi R. Differences in the drought stress response of DREB2 and CAT1 genes and evaluation of related physiological parameters in some bread wheat cultivars. Biotechnology \& Biotechnological Equipment, 2017; 31(4): 709-716.

[DOI: https://doi.org/10.1080/13102818.2017.1316214]

15. Haley S.D., Quick J.S., Morgan J.A. Excised-leaf water status evaluation and associations in field-grown winter wheat. Canadian Journal of Plant Science, 1993; 73(1): 55-63. [DOI: https://doi.org/10.4141/cjps93-008]

16. Hewlett J.D., KramerP.J. The measurement of water deficits in broadleaf plants. Protoplasma, 1963; 57(1-4): 381-389.

[DOI: https://doi.org/10.1007/BF01252067]

17. Kamoshita A., Babu R.C., Boopathi N.M., Fukai S. Phenotypic and genotypic analysis of drought-resistance traits for development of rice cultivars adapted to rainfed environments. Field Crops Research, 2008; 109(1-3): 1-23.

[DOI: https://doi.org/10.1016/j.fcr.2008.06.010]

18. Kaur S., Aulakh J., Jhala A.J. Growth and seed production of glyphosate-resistant giant ragweed (Ambrosia trifida L.) in response to water stress. Canadian Journal of Plant Science, 2016; 96(5): 828-836.

[DOI: https://doi.org/10.1139/cjps-2015-0309]

19. Khomenko S.O., Vlasenko V.A., Chugunkova T.V., Fedorenko I.V., Berezovskyi D.Yu., Daniuk T.A. Creation of bread spring wheat breeding material with wheat-rye translocations.

Plant Varieties Studying and Protection, 2019; 15(1): 18-23. (In Ukrainian)

[DOI: https://doi.org/10.21498/2518-1017.15.1.2019.162477]

20. Klymiuk V., Fatiukha A., Huang L., Wei Zh., Kis-Papo T., Saranga Ye., Krugman T., Fahima T. Durum Wheat as a Bridge Between Wild Emmer Wheat Genetic Resources and Bread Wheat, Chapter 10 Ed.(s): Miedaner T., Korzun V., In Woodhead Publishing Series in Food Science, Technology and Nutrition, Applications of Genetic and Genomic Research in Cereals, Woodhead Publishing, 2019: 201-230.

[DOI: https://doi.org/10.1016/B978-0-08-102163-7.00010-7]

21. Larchenko K.A., Morgun B.V. Wheat grain quality traits and methods of their improvement. Physiology and Biochemistry of Cultivated Plants, 2010; 42(6): 463-474. (In Ukrainian)

22. Lozinska T.P. The productive potential of new varieties of spring wheat under conditions of Ukraine Forest Steppe. Bulletin of Sumy NAU, 2015; 3(29): 55-69. (In Ukrainian)

23. Lugojan C., Ciulca S. Evaluation of relative water content in winter wheat. Journal of Horticulture, Forestry and Biotechnology, 2011; 15(2): 173-177.

24. Merchuk-Ovnat L., Barak V., Fahima T., Ordon F., Lidzbarsky G. A., Krugman T., Saranga Ye. Ancestral QTL Alleles from Wild Emmer Wheat Improve Drought Resistance and Productivity in Modern Wheat Cultivars. Front. Plant Sci., 2016; 8: [DOI: https://doi.org/10.3389/fpls.2016.00452]

25. Mohamadi N., Rajaei P. Effect of Triamidefon fungicide on some growth parameters and antioxidant enzymes activity in tomato (Lycopersicom esculentum Mill.) plant under drought stress. International J. of Advanced Biological and Biomedical Research, 2013; 1(4): 341-350. [DOI: https://doi.org/10.26655/ijabbr.2016.12.2] 
26. Müller C., Elliott J., Chryssanthacopoulos J., Deryng D., Folberth C., Pugh T.A.M., Schmid E. Implications of climate mitigation for future agricultural production. Environmental Research Letters, 2015; 10(12): 2-13.

[DOI: https://doi.org/10.1088/1748-9326/10/12/125004]

27. Newton A.C., Johnson S.N., Gregory P.J. Implications of climate change for diseases, crop yields and food security. Euphytica, 2011; 179(1): 3-18.

[DOI: https://doi.org/10.1007/s10681-011-0359-4]

28. Parker L., Bourgoin C., Martinez-Valle A., Läderach P. Vulnerability of the agricultural sector to climate change: The development of a pan-tropical Climate Risk Vulnerability Assessment to inform sub-national decision making. PLoS One, 2019; 14(3): e0213641.

[DOI: 10.1371/journal.pone.0213641; PMCID: PMC6436735]

29. Peleg Z., Fahima T., Abbo S., Krugman T., Nevo E., Yakir D., Saranga Y. Genetic diversity for drought resistance in wild emmer wheat and its ecogeographical associations. Plant, Cell and Environment, 2005; 28(2): 176-191.

[DOI: https://doi.org/10.1111/j.1365-3040.2005.01259.x]

30. Porter J.R., Semenov M.A. Crop responses to climatic variation. Phil. Transact. Royal Soc. B-Biol. Sci., 2005; 360: 2021-2035.

[DOI: https://doi.org/10.1098/rstb.2005.1752]

31. Prudhomme C., Giuntoli I., Robinson E.L., Clark D.B., Arnell N.W., Dankers R., Fekete B.M., Franssen W., Gerten D., Gosling S.N., Hagemann S., Hannah D.M., Kim H., Masaki Y., Satoh Y., Stacke T., Wada Y., Wisser D. Hydrological droughts in the 21st century, hotspots and uncertainties from a global multimodel ensemble experiment. Proc Natl Acad Sci USA, 2014; 111(9): 3262-3267.

[DOI: https://doi.org/10.1073/pnas.1222473110; PMCID: PMC3948235]

32. Raza A., Razzaq A., Mehmood S. S., Zou X., Zhang X., Lv Y., Xu J. Impact of Climate Change on Crops Adaptation and Strategies to Tackle Its Outcome: A Review. Plants (Basel). 2019; 30; 8(2): 34 .

[DOI: https://doi.org/10.3390/plants8020034; PMID: 30704089; PMCID: PMC6409995]

33. Ritchie S.W., Nguyen H.T., Holaday A.S. Leaf water content and gas-exchange parameters of two wheat genotypes differing in drought resistance. Crop Science, 1990; 30(1): 105-111. [DOI: https://doi.org/10.2135/cropsci1990.0011183x003000010025x]

34. Shewry P.R. Wheat. Journal of Experimental Botany, 2009; 60(6): 1537-1553. [DOI: https://doi.org/10.1093/jxb/erp058]

35. Sobhaninan N., Heidari B., Tahmasebi S., Dadkhodaie A., Mclntyre C.L. Response of quantitative and physiological traits to drought stress in the SeriM82/Babax wheat population. Euphytica, 2019; 215(2): 1-15. [DOI: https://doi.org/10.1007/s10681-019-2357-x]

36. State register of plant varieties suitable for dissemination in Ukraine in 2017. www.sops.gov.ua

37. Tester M., Bacic M. Abiotic stress tolerance in grasses. From model plants to crop plants. Plant Physiology, 2005; 137: 791-793.

[DOI: https://doi.org/10.1104/pp.104.900138]

38. Vlasenko $V$. Estimation of adaptive of bread spring wheat varieties. Plant varieties studying and protection, 2006; 4: 93-103. (In Ukrainian) [DOI: https://doi.org/10.21498/2518-1017.4.2006.68043]

39. Weatherley P.E. Studies in the water relations of the cotton plant. I. The field measurement of water deficits in leaves. New Phytologist, 1950; 49(1): 81-97. [DOI: https://doi.org/10.1111/j.1469-8137.1950.tb05146.x]

40. Wenzel W.G., W.J. van den Berg. Leaf water retention of excised leaves as a measure of drought resistance in grain sorghum (Sorghum bicolor L. Moench) genotypes. South African Journal of Plant and Soil, 1987; 4(1): 31-34.

[DOI: https://doi.org/10.1080/02571862.1987.10634232]

ISSN 1996-4536 (print) • ISSN 2311-0783 (on-line) • Біологічні Студії / Studia Biologica • 2019 • Том 13/№2 • С. 41-54 
41. Xurun Yu, Bo Li, Leilei Wang, Xinyu Chen, Wenjun Wang, Yunjie Gu, Zhong Wang, Fei Xiong. Effect of drought stress on the development of endosperm starch granules and the composition and physicochemical properties of starches from bread and durum wheat. Science of Food and Agriculture, 2016; 96(8): 2746-2754.

[DOI: https://doi.org/10.1002/jsfa.7439]

42. Yadav A.K., Carroll A.J., Estavillo G.M., Rebetzke G.J., Pogson B.J. Wheat drought tolerance in the field is predicted by amino acid responses to glasshouse-imposed drought. Journal of Experimental Botany, 2019; 70(18): 4931-4948. [DOI: https://doi.org/10.1093/jxb/erz224]

43. Yu J., Jiang M., Guo C. Crop Pollen Development under Drought: From the Phenotype to the Mechanism. Int J Mol Sci. 2019; 28; 20(7).

[DOI: https://doi.org/10.3390/ijms20071550; PMCID:PMC6479728]

44. Zadoks J.C., Chang T.T., Konzak C.F. A decimal code for the growth stage of cereal. Weed Research, 1974; 14(6): 415-421.

[DOI: https://doi.org/10.1111/j.1365-3180.1974.tb01084.x]

45. https://geoknigi.com/img/shabliy/karta-gruntiv-lvivskoyi-oblasti.jpg

46. https://past.en.lo4d.com/windows

47. https://www.ncdc.noaa.gov/temp-and-precip/global-maps/201815\#global-maps-select

\title{
ВОДОУТРИМНІ ВЛАСТИВОСТІ ЛИСТКІВ ЯК ПОКАЗНИК ПОСУХОСТІЙКОСТІ УКРАЇНСЬКИХ СОРТІВ ПШЕНИЦІ ЯРОЇ
}

\author{
О. О. Макар ${ }^{1}$, О. І. Пацула', Я. 3. Кавулич', Т. І. Батрашкіна', \\ Л. В. Буньо ${ }^{1}$, В. І. Козловськийㄹ, О.К. Ватаманюк ${ }^{3}$, О. І. Терек', Н. Д. Романюк \\ 1 Львівський національний університет імені Івана Франка, \\ вул. Грушевського, 4, Львів 79005, Україна \\ ${ }^{2}$ Інститут Екології Карпат НАН України, вул. Козельницька, 4, Львів 79026, Україна \\ ${ }^{3}$ Школа інтегративних наук про рослини, \\ Корнельський Університет, Ітака, штат Нью-Йорк, США \\ Кореспондуючий автор: orysia.makar@Inu.edu.ua
}

Досліджено посухостійкість 24 генотипів пшениці ярої української селекції (Triticum aestivum L., T. durum Desf., T. turgidum subsp. Dicoccum) способом визначення показників водного дефіциту (WD), відносного вмісту води (RWC), водоутримної здатності у перерахунку на масу (EL WLW) і площу (EL WLA) прапорцевих листків рослин в умовах польового експерименту протягом вегетаційного сезону 2018 р., який характеризувався низьким рівнем опадів і високими температурами. Експериментальні ділянки були розташовані поблизу с. Дмитрів Львівської обл. $\left(50^{\circ} 13^{\prime} 26,6^{\prime \prime} \mathrm{N} 24^{\circ} 36^{\prime} 50,5^{\prime \prime} \mathrm{E}\right)$ на чорноземах на елювії карбонатних порід. Пшеницю висівали рандомізованим способом у чотирикратній повторності, площа ділянок

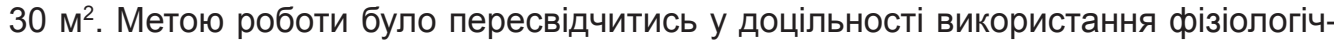
них показників прапорцевих листків для визначення посухостійкості окремих сортів пшениці ярої, їхню залежність із урожаєм. Водні параметри визначали на етапі росту Z4.3. Дефріцит вологи спричинив зменшення відносного вмісту води в листках усіх досліджуваних сортів пшениці. Підтверджено відмінності в реакції на посуху серед сортів пшениці м якої і твердої (T. aestivum і T. durum). Показники водного дефріциту були в межах від 18,0 до 37,8 \% для сортів пшениці м'якої та 19,433,3 \% для твердої. Найнижчий показник WD ( 20 \%) було виявлено для сортів

ISSN 1996-4536 (print) • ISSN 2311-0783 (on-line) • Біологічні Студії / Studia Biologica • 2019 • Том 13/№2 • С. 41-54 
м'якої пшениці Колективна 3, Елегія миронівська і твердої - Діана та Чадо. Високі значення WD відзначено для сортів Сімкода миронівська та МIП Райдужна. Низькі значення WLW EL, а отже, вища посухостійкість відмічена для сортів пшениці твердої Спадщина та Діана. Сорти м'якої пшениці Сімкода миронівська, Панянка та тверді сорти Жізель, Тера, МІП Райдужна та полба Голіковська втратили менше води у перерахунку на одиницю площі листка (EL WLA). Двокомпонентний biplot аналіз підтвердив високу посухостійкість сорту МІП Райдужна і дав змогу виокремити такі сорти з високою урожайністю та посухостійкістю, як Жізель (тверда), Голіковська (полба) і Сімкода миронівська (м'яка). Сорти пшениці м'якої Божена, Дубравка та твердої Спадщина, Діана були сприйнятливими до посухи, незважаючи на відносно високий показник RWC. Отже, показники EL WLW та EL WLA, що характеризують водоутримну здатність тканин листків, можуть бути рекомендовані як додаткові показники стійкості до водного стресу. RWC як параметр посухостійкості доцільно застосовувати для пшениці твердої, тоді як EL WLA 2-6 год - для пшениці м'якої ярої.

Ключові слова: посуха, Українські сорти пшениці ярої, відносний вміст води, водний дефіцит, водоутримна здатність листків, EL WLW, EL WLA

Одержано: 23.10.2019

ISSN 1996-4536 (print) • ISSN 2311-0783 (on-line) • Біологічні Студії / Studia Biologica • 2019 • Том 13/№2 • C. 41-54 